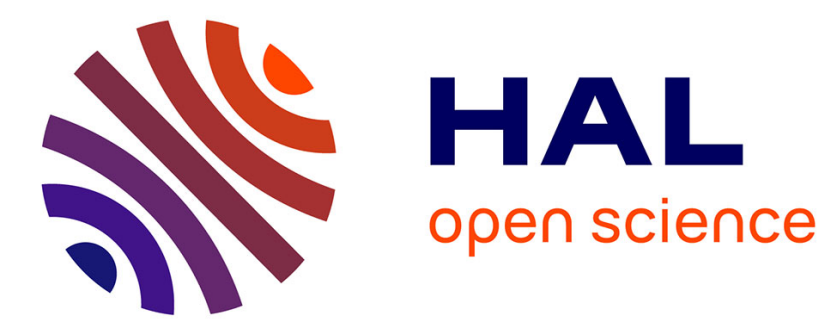

\title{
Exploring the Influential Factors of e-Banking Satisfaction in Rural Areas in China
}

Mengyu Ren, Yan Li, Yu Wang, Zihao Zhao

\section{To cite this version:}

Mengyu Ren, Yan Li, Yu Wang, Zihao Zhao. Exploring the Influential Factors of e-Banking Satisfaction in Rural Areas in China. 8th International Conference on Computer and Computing Technologies in Agriculture (CCTA), Sep 2014, Beijing, China. pp.371-378, 10.1007/978-3-319-19620-6_42 . hal01420253

\section{HAL Id: hal-01420253 \\ https://hal.inria.fr/hal-01420253}

Submitted on 20 Dec 2016

HAL is a multi-disciplinary open access archive for the deposit and dissemination of scientific research documents, whether they are published or not. The documents may come from teaching and research institutions in France or abroad, or from public or private research centers.
L'archive ouverte pluridisciplinaire HAL, est destinée au dépôt et à la diffusion de documents scientifiques de niveau recherche, publiés ou non, émanant des établissements d'enseignement et de recherche français ou étrangers, des laboratoires publics ou privés. 


\title{
Exploring the influential factors of e-banking satisfaction in rural areas in China
}

\author{
Mengyu Ren ${ }^{1, \mathrm{a}}$, Yan $\mathrm{Li}^{1, \mathrm{~b} *}$, Yu Wang ${ }^{1, \mathrm{c}}$, Zihao Zhao ${ }^{1, \mathrm{~d}}$ \\ ${ }^{1}$ International College, China Agricultural University, Beijing 100083, China

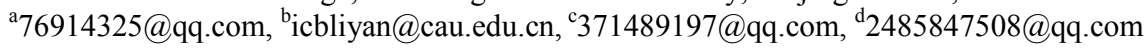

\begin{abstract}
Online banking has become a new and popular business in recent years. What factors influence the success of online banking and how can online banking get a larger development have drawn much research interest of people. This paper mainly focuses on the research of online banking standing at the users' view. It will explore the factors that influence the satisfaction of customer. Through this paper, we would not only get the new awareness about the factors affecting the users' satisfaction about online banking, but also gain the profound reflection of the future way regarding the online banking.
\end{abstract}

Keywords: online banking, satisfaction, rural areas

\section{Introduction}

With rapid growth and development of information and network technology, banks have been deeply affected and they are going through unprecedented changes. Those traditional banking businesses are now far behind and left by those online banking businesses since online banking has been bringing people much more convenience [1]. More precisely, with the help of online banking, people can access to banking transactions instead of going to banking institutions [2].

In recent years, along with the economic growth and the popular usage of computer and cell phone in rural areas, the Internet has created tremendous need of using e-banking services in suburban in China [3]. However, restricted by the traditional thought of have the financial activities in the banks and the limited layout of bank site, the development of online banking service is still facing with difficulties. For example, there are only 150,000 people among 505,000 have their online banking accounts in Yutian county, Xinjiang province. The results of former research on rural people showed that $30 \%$ of the rural people opened their online banking [4]. The reason of the acceptance of online banking services is that they were recommended, not for their personal needs. Besides, half of them choose to use online banking because there are less commission charges. According to the previous study, the main difficulties that online banking service has faced with are, for example, some people are not capable with using the computer and the Internet; rural population are not committed to financial products; online banking products and services lack innovation.

Therefore, determining the main factors influencing customers' satisfaction can be valuable for service providers to make better improvements. In other words, to

\footnotetext{
* Corresponding author.
} 
increase the popularity of using online banking among rural population, banks have to put more emphasis on understanding the needs of rural customers. In this study, we develop a research model basing on reviewing previous literature and test out the relative importance between customer satisfaction level and the main five influential factors, which are system quality, information quality, service quality, trust and switching cost.

\section{Theoretical Background}

\subsection{System quality}

System quality is the measure of information processing system itself [5]. System quality can be measured using ease of learn, ease of use, efficiency, stability and security. Ease of learn denotes a feeling of customer that the system is easy to access. Ease of use can provide convenience to customer when using the system and let people prefer to use the system as well. Efficiency often relates to response time, the less the response time the more customer can be satisfied. Stability means the quality or state of being steady, which creates a sense of reliable from consumers. Security is another important factor that affects consumers' satisfaction. Sathye found that $70 \%$ of customers expressed their concerns on security [6]. Hence, it is assumed that system quality positively affects the consumer's satisfaction.

$\mathrm{H1}$ : There is positive relationship between system quality and satisfaction.

\subsection{Trust}

"Willingness to rely on an exchange partner in whom one has confidence" is what trust means [7]. Trust in online banking is a new and emerging area of interest in research. Researchers found that trust will affect satisfaction in the long term [8]. A customer's satisfaction will be enhanced over time, if his or her feeling of faith in the provider is satisfied [9]. Hence, it is assumed that trust effects positively on consumers' satisfaction of online banking system.

$\mathrm{H} 2$ There is a positive relationship between trust and satisfaction.

\subsection{Service Quality}

Service quality refers to the overall support delivered by the service providers. Dabholkar, Shepherd, and Thorpe stated that since service quality had sub-dimensions of reliability and responsiveness, it would lead to customer satisfaction [10]. Researchers maintain that perceived service quality is cognitive and thus followed by satisfaction [11]. With the development of online banking, increasing managers realize that service play an extreme role in the banking. Several empirical studies confirmed that a higher level of service quality was related to a higher level of customer satisfaction. SERVQUAL theory is an important theory to give the way of 
measuring the service quality [12]. The theory elaborated that quality included five dimensions: reliability, tangibles, responsiveness, assurance, and empathy. And we will design our questions of service quality based on these metrics.

H3. There is a positive relationship between service quality and satisfaction.

\subsection{Information Quality}

Information quality is a measure of information system output. Information quality refers relevance, usefulness, informativeness, timeliness, completeness and clarity to the users' satisfaction level [12]. Previous studies have demonstrated the significant effects of relevance, which includes relevant depth and scope that can affect bank expertise. Usefulness denotes a feeling of customer that the information is helpful and useful to learn. Informativeness guarantees the users to gain as much information as they should know. Timeliness refers to whether the information is the latest or not, the more often banks update their information, the more their customers can be satisfied. Completeness and clarity are other two key factors. The degree of completeness and clarity is positively related to users' satisfaction level.

$\mathrm{H} 4$. There is a positive relationship between information quality and satisfaction.

\subsection{Switching Cost}

Switching cost is the costs that the consumer incurs by changing one service provider to another [13]. It can be a barrier to change service providers so that the online banking providers are typical beneficiaries. Thus it is a way for improving customer loyalty as well as the customer satisfaction [14]. As a direct effect on customer satisfaction, switching cost offers many advantages for service providers. For instance, it weakens customers' sensitivity to price and satisfaction of the product brand [15]. Specifically, if the customers know the risks of switching their current online transaction way to other ways, such as the trouble in building a new contact relationship, the difficulty in using an alternative service, a long and complex proceed to learn, as well as the time waste of using other transaction method, it will increase the probability that they keep the relationship with the current online banking transaction method. We assume that there is a positive and strong relationship between switching cost and satisfaction. In this paper, we will test their concrete relationship regarding online banking.

H5. There is a positive relationship between switching cost and satisfaction.

\section{$3 \quad$ Research Model}

Based on the theoretical background discussed above, this study establishes a research model which suggests five links involved in customer satisfaction regarding the online banking. As showed in Fig. 1, consumers' satisfaction is positively influenced by system quality, trust, service quality, information quality and switching cost. Table 1. shows the main 24 attributes of measuring the five factors. 
Table 1. Measurement of five factors

\begin{tabular}{|c|c|}
\hline Factors & Items of measurement \\
\hline \multirow[t]{5}{*}{ System quality } & Online banking is easy to learn. \\
\hline & Online banking is easy to use. \\
\hline & Online banking system can quickly deal with my business. \\
\hline & Online banking will not reveal my information and privacy without allowance. \\
\hline & Online banking system is stable, no error. \\
\hline \multirow[t]{6}{*}{ Information quality } & Online banking is able to give users financial news. \\
\hline & Online banking is able to provide me the various information. \\
\hline & Online banking is able to provide me with information that I need. \\
\hline & Online banking is able to provide me information of the latest financial products. \\
\hline & Online banking are able to provide me with complete information. \\
\hline & Online bank's website is designed clear and easy to read. \\
\hline \multirow[t]{3}{*}{ Service quality } & $\begin{array}{l}\text { Some related department of bank will give me help when I meet with difficulties } \\
\text { while using online banking. }\end{array}$ \\
\hline & The service representative of online banking is polite and worth trust. \\
\hline & Online banking provides personal service according to users' needs. \\
\hline \multirow[t]{3}{*}{ Trust } & I think banks that provide online banking service are with high reputation. \\
\hline & I think banks give much care to its users. \\
\hline & I think banks that provide online banking service is reliable. \\
\hline \multirow[t]{4}{*}{ Switching cost } & Going to the counter gives me much more trouble rather than using online banking. \\
\hline & Going to the counter is more expensive compared with using online banking. \\
\hline & Going to the counter requests me to learn how to manipulate. \\
\hline & Going to the counter wastes my time compared to using online banking. \\
\hline \multirow{3}{*}{$\begin{array}{l}\text { Customer } \\
\text { satisfaction }\end{array}$} & I will keep using online banking. \\
\hline & I will recommend others to use online banking. \\
\hline & In general I am satisfied with using online banking. \\
\hline
\end{tabular}




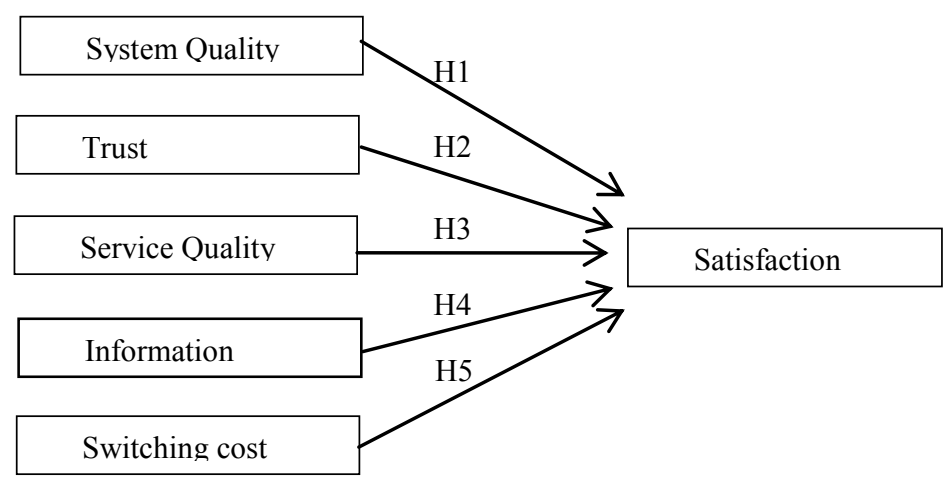

Fig. 1. The proposed research model

\section{$4 \quad$ Research Methods}

In June 2013, after pretested by some online banking users and reviewed by three professional experts in related area, our questionnaire was revised based on their feedback and suggestions. 200 questionnaires were collected in Chang Ping County in Beijing and hand out. After eliminating insincere and incomplete responses through data filtering, we got a total number of 150 usable responses. All data will be analyzed by using SPSS and LISREAL software.

The descriptive statistics of the sample are listed in Table 2. Of the 150 participants, $53 \%$ are males, $47 \%$ are females, and more than half of respondents are below 35 years old. Most of them are young people. The enterprise staff and farmers are the main research respondents. As for disposable income, the majority of respondents have disposable income between 1,000 and 3,000RMB. As for family structure, typical "three in one family" is still the most common structure while there are many big families with more than 3 family members. For the network-using frequency, with the popularity of computer, most people can use Internet every day. It is also an important factor contributing to the popularity of online banking.

Table 1. The profile of sample demographics

\begin{tabular}{llll}
\hline Variable & & Count & $\%$ \\
\hline Gender & Male & 79 & $53 \%$ \\
Age & Female & 71 & $47 \%$ \\
& $<20$ & 36 & $24 \%$ \\
& $21-35$ & 54 & $36 \%$ \\
Occupation & $36-50$ & 50 & $33 \%$ \\
& $>50$ & 10 & $7 \%$ \\
& Government staff & 24 & $16 \%$ \\
& Enterprise staff & 36 & $24 \%$ \\
& Small business owners & 27 & $18 \%$ \\
Disposable income per month & Teachers & 5 & $3 \%$ \\
& Farmers & 36 & $24 \%$ \\
& Students & 22 & $15 \%$ \\
\hline
\end{tabular}




\begin{tabular}{llll}
\hline & $1000-1500$ & 58 & $39 \%$ \\
& $1500-3000$ & 40 & $28 \%$ \\
Family members & $3000-4500$ & 20 & $13 \%$ \\
& $4500-6000$ & 11 & $7 \%$ \\
Network-using frequency & $>6000$ & 9 & $5 \%$ \\
& 1 & 10 & $7 \%$ \\
& 2 & 20 & $13 \%$ \\
& 3 & 70 & $47 \%$ \\
& $>3$ & 50 & $33 \%$ \\
& More than 6 hours everyday & 24 & $16 \%$ \\
& Less than 6 hours everyday & 68 & $45 \%$ \\
& Several times per week & 35 & $23 \%$ \\
& Several times per month & 18 & $12 \%$ \\
& Several times per year & 5 & $34 \%$ \\
\hline
\end{tabular}

\section{$5 \quad$ Results and Discussion}

As shown in Fig. 2, Hypothesis H1 that system quality positively influences users' satisfaction $(\beta=0.511)$ was supported. System quality was partially the determinant of customer satisfaction. Almost $90 \%$ of respondents believe that online banking is easy to use and is easy to learn and $31.3 \%$ of them strongly agree with this. $82.6 \%$ of respondents agree that online banking can easily deal with business. This result demonstrates the importance of system quality in building the customers' satisfaction in online banking system. Similar to Sathye's finding, almost $70 \%$ of customers expressed their concerns on satisfaction [6]. Especially in suburban, the education level is not high, easy to learn and easy to use the system is extremely important to make people be satisfied, which is consistent with the result.

Hypothesis $\mathrm{H} 2$ that trust positively influences users' satisfaction $(\beta=0.526)$ was supported. $74.6 \%$ of respondents agree that the bank which provides online banking service has high reputation. $60 \%$ of respondents think that banks which provide online banking service is reliable. That implies a large number of online banking users trust that banks are able to provide high quality service in online banking. This result is consistent with earlier finding conducted by Kim, Ferrin and Rao (2009) that trust will affect satisfaction in the long term [9]. The data collected indicates that reliability of online banking service providers is a key to enhance satisfaction. We thought there is no difference between suburban area and urban area on the term that trust affects satisfaction of customers on online banking.

Hypothesis $\mathrm{H} 3$ that service quality positively influences users' satisfaction $(\beta=0.247)$ was not strongly supported. A result can be explained by the characteristic of the system. The conception of "e-service" emerged on the growth of the Internet. Initially, firms developed an online presence due to the cost reductions that could be gained from automation [10]. The online banking system emphasizes on self-using which means people can easily finish the transaction or other financial activities themselves by using the Internet instead of going to the bank personally or communicate with the bank representatives. Consequently, the service provided by departments and representatives of bank has a weak correlation with users' satisfaction. In the meanwhile, the ease of use of the online banking system is still a large barrier of the online banking usages. The bank should consider improving the 
service quality through the services provided by both the bank staff and the online systems.

Hypothesis $\mathrm{H} 4$ that information quality positively influences users' satisfaction ( $\beta=0.288)$ was not strongly supported. It explains the purpose of users to use online banking system. According to the survey, most people use the online banking system in order to finish transfer transaction and currency exchange conveniently. They are not focusing on the financial information the online banking system provided because merely a small portion of people use online banking system to buy financial product.

Hypothesis $\mathrm{H} 5$ that switching cost positively influences users' satisfaction ( $\beta=0.680)$ was strongly supported. This result tells us that customers are willing to use the system if it can save time and money. Especially in suburban, the salary level is not very high. The lower the cost, the more customers will be satisfied.

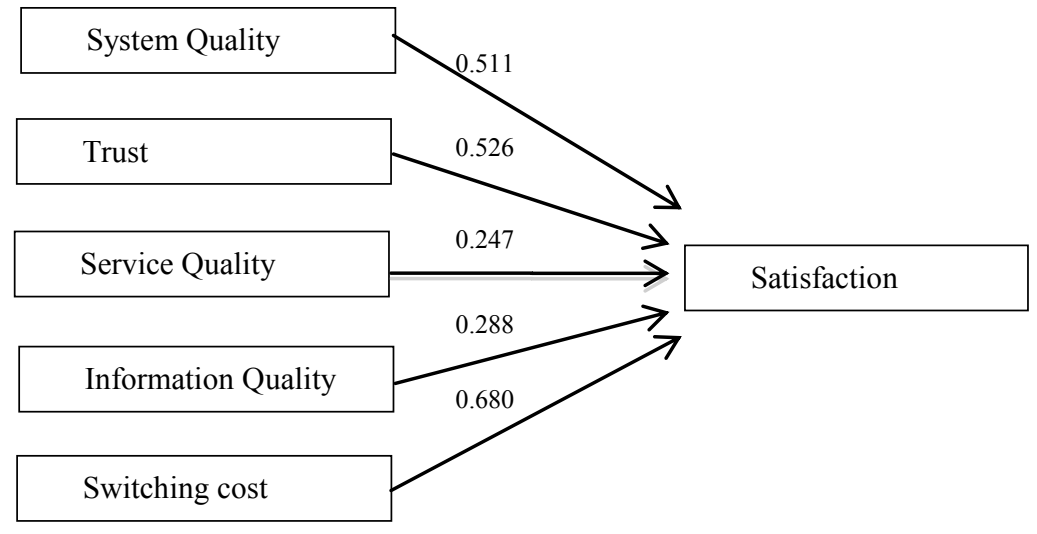

Fig. 2. Results of structural modeling analysis

\section{Conclusion}

E-banking is fast becoming norm in China, and e-banking system has been adopted by more and more users in rural areas in China. It forces most financial institutions to re-examine their systems and practices and to look for new ways to deliver their services over the Web. E-banking system evaluation does not have committed guidelines and models. Although the past researches evaluate the system effectiveness from different aspects, it was considered more suitable to evaluate the system in terms of users' satisfaction. A research model was developed basing on reviewing previous literature and test out the relative importance. As a result, this research model considers more aspects and help system designers and managers find out the system problems and factors needing improvement. Among all the influential factors, switching cost, trust and system quality are the dominant effects on the satisfaction. As the e-banking system is in the introduction period in rural market, users are more sensitive to the cost, the ease of use of the system and the trust to the bank, rather than the quality of the information and service that the system can provide to them. 
Therefore, the banks may develop the appropriate strategies copying with the users' current demand and changes in the future. .The main limitations should be noted are the single site of sampling and the criteria of the assessment.

\section{References}

1. Xina Yuan, Hyung Seok Lee, Sang Yong Kim. Present and Future of Internet Banking in China[J]. Journal of Internet Banking and Commerce, 2010, 15: 3-9.

2. Sherah Kurnia, Fei Peng, Yi Ruo Liu. Understanding the Adoption of Electronic Banking in China [J]. The University Of Melbourne Press, 2009.

3. Xiaohui Chen. Farmers become netizens after the Internet access in rural areas in China. Chinese Financial News. 20th June 2013. Available from: http://www.financialnews.com.cn/dfjr/jyjl/201306/t20130620_35152.html. [Accessed: 4th August 2013]

4. Wu Li. The difficulties and strategies of online banking in rural areas in China. GWYOO website. Available from: http://www.gwyoo.com/lunwen/yinhanglunwen/yhfzlw/201209/540137.html. [Accessed: 4th August 2013]

5. William DeLone, and Ephraim McLean. Information System Success: The Quest for Dependent Variable [J]. Information Systems Research, 1992, 3(1): 60-95.

6. Milind Sathye. Adoption of Internet banking by Australian consumers: an empirical investigation [J]. International Journal of Bank Marketing, 1999, 17: 324-334.

7. Moorman, Christine, Rohit Deshpande and Geraldzaltman. Factors Affecting Trust in Market Research Relationship [J]. Journal of Marketing, 1993, 81-101.

8. Garbarino, Ellen, and Mark Johnson. The different roles of satisfaction, trust, and commitment in customer relationships [J]. Journal of Marketing, 1999, 70-87.

9. Dan Kim, Donald Ferrin, and Raghav Rao. Trust and satisfaction, two stepping stones for successful e-commerce relationships: A longitudinal exploration [J]. Information Systems Research, 2009, 20(2): 237-257.

10. Mary Loonam and Deirdre Loughlin. An observation analysis of e-service quality in online banking [J]. Journal of Financial Services Marketing, 2008, 13(2): 164-178.

11. Pratibha Dabholkar, David Shepherd and Dayle Thorpe. A comprehensive framework for service quality: An investigation of critical conceptual and measurement issues through a longitudinal study [J]. Journal of Retailing, 2000, 76(2): 139-173.

12. Richard Oliver. Whence consumer loyalty? [J]. Journal of Marketing, 1999, 63(4):.33-44.

13. Fan Chuan Tsung and Tsung Han Li. A Study of Assessment of Library E-resource Metasearch System [J]. Journal of Library and Information Studies, 2008, 111-142.

14. Jonathan Lee, Lawrence Feick. The impact of switching costs on the customer satisfaction-loyalty link: Mobile phone service in France [J]. Journal of Service Marketing, 2001, 15(1): 35-48.

15. Alan Dick and Kunal Basu. Customer loyalty: Toward an integrated conceptual framework. [J]. Journal of the Academy of Marketing Science, 1994, 22:99-113. 